2013

\title{
Survey for the Presence of Phytophthora cinnamomi on Reclaimed Mined Lands in Ohio Chosen for Restoration of the American Chestnut
}

Shiv Hiremath

United States. Forest Service. Northern Research Station

Kirsten J. Lehtoma

United States. Forest Service

Jenise Bauman

Western Washington University, jenise.bauman@wwu.edu

Follow this and additional works at: https://cedar.wwu.edu/hcop_facpubs

Part of the Botany Commons, and the Environmental Sciences Commons

\section{Recommended Citation}

Hiremath, Shiv; Lehtoma, Kirsten J.; and Bauman, Jenise, "Survey for the Presence of Phytophthora cinnamomi on Reclaimed Mined Lands in Ohio Chosen for Restoration of the American Chestnut" (2013). Huxley College on the Peninsulas Publications. 11.

https://cedar.wwu.edu/hcop_facpubs/11 
Journal American Society of Mining and Reclamation, 2013 Volume 2, Issue 1

\title{
SURVEY FOR THE PRESENCE OF PHYTOPHTHORA CINNAMOMI ON RECLAIMED MINED LANDS IN OHIO CHOSEN FOR RESTORATION OF THE AMERICAN CHESTNUT ${ }^{1}$
}

\begin{abstract}
Shiv Hiremath ${ }^{2}$, Kirsten Lehtoma, and Jenise M. Bauman
Abstract. We have been planting blight resistant American chestnut seedlings on reclaimed coal mined areas in Southeastern Ohio, which was once within the natural range of the American chestnut. Towards the goal of restoring the American chestnut, we are testing suitable sites that can aid survival, growth and establishment of planted seedlings pre-inoculated with ectomycorrhizal fungi. Prior to the arrival of the chestnut blight fungus, pathogens of the genus Phytophthora were introduced in the USA that were responsible for the "ink disease" or "root-rot" resulting in wide-spread death of chestnut trees in southern states. Although these pathogens were not observed elsewhere, recent reports indicate their presence in some northern states, including Ohio. We have been testing each location targeted for chestnut plantings for the presence of Phytophthora, specifically $P$. cinnamomi. The work reported here shows results obtained from seven different sites in southeastern Ohio where reclamation was done 3-20 years ago. Soil was collected at a depth of 4-5" at several locations within each site. A positive control containing $\sim 4 \mathrm{cfu} / 10 \mathrm{~g}$ soil was used in the analysis. We used two different techniques for identifying the pathogen: 1 . Direct isolation of the pathogen from the soil using selective media; 2. Using chestnut leaves as a baiting technique followed by selection on plates. In both cases, final identification was done by DNA isolation and sequencing using Phytophthora-specific primers. Our results showed that, at least in the locations we tested, $P$. cinnamomi was not detected. Because most of these lands were only recently reclaimed, it is possible that the pathogen may not have established there yet. However, samples from locations that were reclaimed more than 2 decades ago also showed absence of this fungus. Results suggest that this pathogen is either not as wide-spread in Ohio as in southern states or mined sites are not favorable for its existence and spread.
\end{abstract}

Additional Key Words: root colonization of fungi, chestnut restoration.

\footnotetext{
${ }^{1}$ Paper was presented at the 2012 National Meeting of the American Society of Mining and Reclamation, Tupelo, MS Sustainable Reclamation June 8-15, 2012 and accepted for the online Journal of The American Society of Mining and Reclamation, Volume 2, No. 1, 2013. R.I. Barnhisel (Ed.) Published by ASMR, 3134 Montavesta Rd., Lexington, KY 40502.

2 Shiv Hiremath is a Research Scientist and Kirsten Lehtoma a Biological Technician with USDA Forest Service, Delaware, OH 43015M. Jenise Bauman is Director of Conservation Science Training at The Wilds, Cumberland, $\mathrm{OH} 43732$.
} 


\section{$\underline{\text { Introduction }}$}

The American chestnut (Castanea dentata), once a major component of the eastern US forests, has been almost eliminated by the invasive fungus Cryphonectria parasitica (Anagnostakis, 1982). The fungus was first introduced to North America in early 1900 (Anagnostakis, 1987). Once introduced, it quickly spread into its new and defenseless host population which resulted in the American chestnut being reduced to a mere shrub instead of being a dominant tree species. However, extensive research efforts during the last two decades have given hope for restoring this important forest tree to its once natural range. Two main lines of research were initiated to achieve this goal, one targeted the fungus and the other the tree itself. The first focused on the "hypovirulence" phenomenon and application of genetic engineering technology to cure the blight through hypovirus-mediated transformation of the virulent fungus (Nuss, 2005; Root et al., 2005). Although considerable progress has been made, this approach has not proven to be useful in curbing and curing the blight. However, the second approach of breeding a hybrid resistant chestnut tree has shown considerable success. While the American chestnut is susceptible to the blight causing fungus, its counterpart from Asia the Chinese chestnut (Castanea mollissima), is resistant to the blight fungus. In order to restore the American chestnut to forests, researchers have been engaged in breeding programs to develop a blight-resistant American chestnut (Burnham et al., 1986; for details see www.acf.org). The reason for seeking a resistant American species for restoration instead of using the already resistant Chinese species is largely due to differences between the two species with respect to stature. Although the Chinese chestnut is blight-resistant, it lacks the superior timber qualities of the American chestnut. The American chestnut is significantly larger than the Asian species, which is more of an orchard type tree. The ideal progeny, therefore, should have the blight resistance coupled with the favorable traits of the American species. In order to achieve this, the American Chestnut Foundation (TACF) initiated a backcross-breeding program, which integrates Chinese blight resistance with genes related to the American timber form. Presently, TACF has developed a progeny, which by estimation is 15/16 American. In addition to these efforts, a third front has emerged where researchers are utilizing genetic engineering technology to incorporate resistant genes into the American chestnut (Maynard et al., 2008; Sisco et al., 2009).

We have been working on the restoration of American chestnut in Southeastern Ohio, which was part of its natural range (Hiremath and Lehtoma, 2007; Bauman et al., 2011a; Bauman et al., 
2011b). Some of these lands have been severely affected by extensive mining operations for several decades. However, reclamation and reforestation work has been going on in many locations. Many researchers, including us, have been attempting to introduce the backcrossed hybrid chestnuts in these locations. Because of the harsh soil conditions for tree survival in these locations due to mining, we have incorporated utilization of ectomycorrhizal fungi in the restoration efforts (Hiremath and Lehtoma, 2007). Mycorrhizal fungi may play a vital role in tree restoration efforts. These fungi are often essential for the survival of trees by supporting growth under a variety of suboptimal soil and other stress conditions (Danielson, 1985). In addition to providing support to the plant with respect to nutrient availability and adaptation to extreme $\mathrm{pH}$ conditions, the mycorrhizal fungi are also known to provide protection from other harmful pathogens.

Long before the blight fungus came to North America, several pathogens of the genus Phytophthora were introduced in late the 1700s or early 1800s (Jeffers et al., 2009) . Among these, $P$. cinnamomi was responsible for the "ink disease" or "root-rot" in chestnut that resulted in widespread death of chestnut trees in southern states. Its presence in the northeastern states, and especially in the Appalachian region, has been noticed on chestnut seedlings recently (Rhoades et al., 2003). It was responsible for significant mortality observed in recent plantings of chestnut seedlings in Kentucky and neighboring states (Rhoades et al., 2003 and 2009). However, there is very little information about the extent of its spread, especially in reclaimed mined lands of Ohio. Since our plantings will be in these locations, we undertook the following study of a survey of this pathogen in locations that were reclaimed recently (2-3years ago) as well as in regions that were reclaimed $\sim 20$ years ago.

\section{$\underline{\text { Methods }}$}

\section{$\underline{\text { Sites and Soil Collection }}$}

We tested soil from several locations indicated in Table 1. Most of these sites were within the Wayne National Forest, Ohio and in The Wilds of Ohio. All of these locations were abandoned coal mined areas and reclamation in these sites was undertaken between 3-20 years prior to collecting samples for testing. In older reclaimed areas there were both existing grassland and unaffected forest stands nearby. Soil was collected from 2-10 sites (randomly 
selected) of each location and used for the isolation of the fungus. Soil sample collections were done during spring to early fall when conditions are not unfavorable for the pathogen.

Table 1. Sites and Phytophthora Assay results. Greendale, OH, Ora Anderson Park site, Straitsville and Nelsonville sites are within the Wayne National Forest (WNF). Number of sites varied at each location because of available space.

\begin{tabular}{|c|c|c|c|c|}
\hline YEAR & LOCATION & SITES & METHOD & DETECTION \\
\hline \multirow[t]{2}{*}{2008} & Greendale, Ohio & 8 & Direct plating & None \\
\hline & $\begin{array}{l}\text { Ora Anderson Park site, } \\
\text { Ironton District, WNF }\end{array}$ & 6 & Direct plating & Pythium sp. in one site \\
\hline \multirow[t]{4}{*}{2009} & The Wilds, near parking lot & t 4 & Direct plating & None \\
\hline & The Wilds, Lake Trail & 4 & Direct plating & None \\
\hline & The Wilds, Site 2 & 4 & Direct plating & None \\
\hline & Nelsonville, Ohio & 5 & Direct plating & None \\
\hline \multirow[t]{3}{*}{2011} & The Wilds, Site 1 & 7 & Leaf baiting & $\begin{array}{l}\text { genus-specific band in } 1 \\
\text { sample not sequenced }\end{array}$ \\
\hline & The Wilds, Forest Site C07 & 7 & Leaf baiting & $\begin{array}{l}\text { Phytophthora citricola } \\
\text { at } 1 \text { site }\end{array}$ \\
\hline & New Straitsville, $\mathrm{OH}$ & 10 & Leaf baiting & $\begin{array}{l}\text { Phytophthora citricola } \\
\text { at } 2 \text { sites }\end{array}$ \\
\hline
\end{tabular}

\section{Isolation of the Fungus}

Soil was collected during spring to early fall seasons by digging at a depth of 4-5 in, placed in plastic Ziploc ${ }^{\circledR}$ bags, and stored at $22^{\circ} \mathrm{C}$ in the dark until used. We used two techniques for isolating the fungus. One was a variation of the soil dilution plating method described by Johnson and Curl (1972) for Phytophthora cinnamomi. Ten grams of soil (after mixing the collected soil thoroughly) were stirred in $100 \mathrm{ml} \mathrm{dH} 2 \mathrm{O}$ in a beaker. Then $20 \mathrm{ml}$ were poured onto PAR(PH)-V8 selective medium plates ( $50 \mathrm{ml} / \mathrm{L}$ buffered, clarified V8 juice, $15 \mathrm{~g} / \mathrm{L}$ Difco Bacto agar, 5ppm pimaricin, $250 \mathrm{ppm}$ sodium ampicillin, $10 \mathrm{ppm}$ rifamycin SV sodium salt, 50 ppm pentachloronitrobenzene, $50 \mathrm{ppm}$ 3-hydroxy-5-methylisoxazole). A positive control containing $\sim 4 \mathrm{cfu} / 10 \mathrm{~g}$ soil was used in the analysis. Plates were incubated in the dark at $22^{\circ} \mathrm{C}$. After 2 days, the soil was rinsed from the plates and incubation was continued for an additional 2-3 days. The plates were examined under a dissecting microscope for the presence of $P$. 
cinnamomi hyphae and subcultures were made on the same selective medium to obtain a pure culture. The fungus was allowed to grow for 3 weeks and harvested.

The second method involved a leaf-baiting technique where $250 \mathrm{~g}$ of soil from each collection site was mixed with $1.25 \mathrm{~L}$ deionized water in Pyrex trays and a single young American chestnut leaf was floated on the surface of the water. After 3-5 days, necrotic areas of the leaf margins were examined with a dissecting scope for fungal sporangia. These areas were plated onto PAR(PH)-V8 plates as described above to obtain a pure culture (Balci et al., 2007).

\section{Isolation of Fungal DNA, PCR Analysis and DNA Sequencing}

After initial identification by morphological characteristics, the final identification of the fungus was made by sequencing the internal transcribed spacer region of the ribosomal DNA and comparing with sequences in the GENBANK using BLAST analysis (Hiremath and Lehtoma, 2007; Bauman et al., 2011a; Gardes and Brubs, 1993; Bruns et al., 1998; Altshul et al., 1997). To do this, the fungal DNA was extracted from the aerial mycelia of the subcultures. About 10 mg of tissue was homogenized to disrupt cells in an extraction buffer using a bead beater. The extract was directly processed using the QIAgen Mini Plant Kit to isolate the DNA. The final product was collected in $50 \mu \mathrm{l}$ TE buffer (10 mM Tris-HCl, $\mathrm{pH}$ 7.5, containing $1 \mathrm{mM}$ EDTA). PCR reactions were set up in $500 \mu \mathrm{l}$ tubes using $1 \mu \mathrm{l}$ template DNA, 1x NovaTaq buffer $(50 \mathrm{mM}$ $\mathrm{KCl}, 10 \mathrm{mM}$ Tris- $\mathrm{HCl}, \mathrm{pH}$ 9.0, containing $1.5 \mathrm{mM} \mathrm{MgCl}$, $0.1 \%$ Triton $\mathrm{X}-100), 20 \mu \mathrm{M}$ each dNTP, $0.2 \mu \mathrm{M}$ primer Yph1F, $0.2 \mu \mathrm{M}$ primer Yph2R, and 5 units NovaTaq DNA polymerase in $100 \mu \mathrm{l}$ reactions. Reactions were carried out for 40 cycles in Perkin-Elmer thermal cycler under the following temperature regime: $1.5 \mathrm{~min}$ at $96^{\circ} \mathrm{C}, 1 \mathrm{~min}$ at $55^{\circ} \mathrm{C}$, and $2 \mathrm{~min}$ at $72^{\circ} \mathrm{C}$.

We used two sets of primers as indicated in Table 2. The Yph1F and Yph2R were specific for the genus Phytophthora, while the pair Ycin3F and Ycin4R was specific for the species Phytophthora cinnamomi.

Ten microliters of each PCR reaction were analyzed on a $0.7 \%$ agarose gel. Bands produced

from the primer pair were isolated from the gel using the Geneclean ${ }^{\circledR}$ (MP Biochemicals) and the products were sequenced using the respective forward primer at the Plant-Microbe Genomic Facility at the Ohio State University. Sequences were analyzed using the BLAST. 
Table 2. Primers used in PCR. Following primers were used for PCR. Identification of the fungus was done through DNA sequencing of the product followed by comparison to known sequences in the GENBANK.

$$
-3^{\prime}
$$

Yph1F 5'CGACCATKGGTGTGGACTTT3'

Yph2R 5'ACGTTCTCMCAGGCGTATCT3'

Ycin3F 5'GTCCTATTCGCCTGTTGGAA3'

Ycin4R 5'GGTTTTCTCTACATAACCATCCTATAA3'

\begin{tabular}{lrc}
\hline PRIMER PAIR & \multicolumn{2}{c}{ EXPECTED PRODUCT SIZE } \\
& & \\
Yph1F + Yph2R & $470 \mathrm{bp}$ & Phytophthora genus-specific \\
Ycin3F + Ycin4R & $243 \mathrm{bp}$ & Phytophthora cinnamomi-specific \\
\hline
\end{tabular}

\section{$\underline{\text { Results and Discussion }}$}

Our results showed that $P$. cinnamomi was not detected in any of the locations we surveyed (Table 1 and Fig. 1). While the positive controls (Pos 1 and Pos 2) produced a fragment of expected size [ 450 bp with genus-specific (left panel) and $\sim 300$ bp with species-specific primers (right panel)], none of the test samples showed bands of that size. Occasionally, the test samples generated PCR products of a different size such as seen in lane OA-2 of the left panel in

Fig 1. Such bands on further examination were proved to be artifacts and did not correspond to the expected product and/or related to Phytophthora cinnamomi. In the case of OA-2, the band was smaller and its sequence was not related to Phytophthora (see below). In contrast, the positive controls consistently produced the expected size products.

In addition to gel analyses, we analyzed the products by DNA sequencing. The products seen on the gel, including those from the positive controls and artifacts, were isolated and purified using the Geneclean system and their DNA sequence determined. Comparison to known sequences deposited in the GenBank ${ }^{\circledR}$ using the BLAST analysis indicated that the ones in the positive controls were indeed related to $P$. cinnamomi while those from the artifact bands were not related to $P$. cinnamomi.

We also used the genus-specific primers in these analyses (Schena et al., 2008). Although our main goal was to investigate the presence of the species $P$. cinnamomi, we also wanted to determine whether any other Phytophthora species were present in these soils. While no other 
Phytophthora species has been conclusively proven a serious pathogen on the American chestnut, the findings would provide an understanding of the spread and establishment of Phytophthora in reclaimed mine soils as well as in northern regions. As shown in Table 1, we did find the presence of $P$. citricola in a couple of sites. This indicates that at least some of the Phytophthora species are present in these reclaimed lands. However, their presence was not common or widespread. In addition to Phytophthora, we also detected another plant pathogen belonging to the genus Pythium at one of the sites.

Although the destruction caused by the chestnut blight fungus Cryphonectria parasitica on the American chestnut was extensive and described in detail, only recently researchers have begun taking notice of the potential threat posed by $P$. cinnamomi on the chestnut tree. There are two different reasons for this. The Phytophthora spp were introduced in the southern forests and caused the widespread damage to forest trees and other plants in southern forests. Although the severe damage caused by different species of Phytophthora was recorded for many years, the first systematic study of the pathogenicity of P. cinnamomi was carried out by Crandall et al., (1945). They looked at the pathogenicity of this species on several thousands of North American plants and found that the pathogen caused severe damage to nearly 800 plants. This included several forest timber trees, including the American chestnut. It is not known how many chestnut trees existed in southern forests that were affected by the pathogen after its introduction. Although there is not clear evidence, it is believed that the natural range of the American chestnut once extended all the way to Florida and Mississippi, and that $P$. cinnamomi was responsible for its demise in the southern forests (Fei, 2007). The second reason the threat of $P$. cinnamomi went unnoticed on chestnut trees could be due to the timing of $C$. parasitica introduction. Before P. cinnamomi could move north, the blight fungus had already established there and was moving fast towards the south. In any case, $P$. cinnamomi is a serious pathogen for the American chestnut as seen on recent plantings (last 5-6 years) and a great threat for the restoration efforts (Rhoades et al., 2007 and 2009). Once infected, it can cause tree mortality much faster than the $C$. parasitica.

The PCR products obtained by using genus-specific (Yph1F and Yph2R) and P. cinnamomispecific (Ycin3F and Ycin4R) primer pairs were analyzed by gel electrophoresis and visualized under UV light. Both negative (Neg) and positive (Pos 1 and 2) controls were included in the analysis. Figure 1 shows results of some of the test samples (OA-1, 6-1 and 6-2). The lane 
marked M shows the DNA molecular weight standards used for estimating the sizes of the products. Some of the marker sizes in Kbp (Kilo base pairs) are indicated.

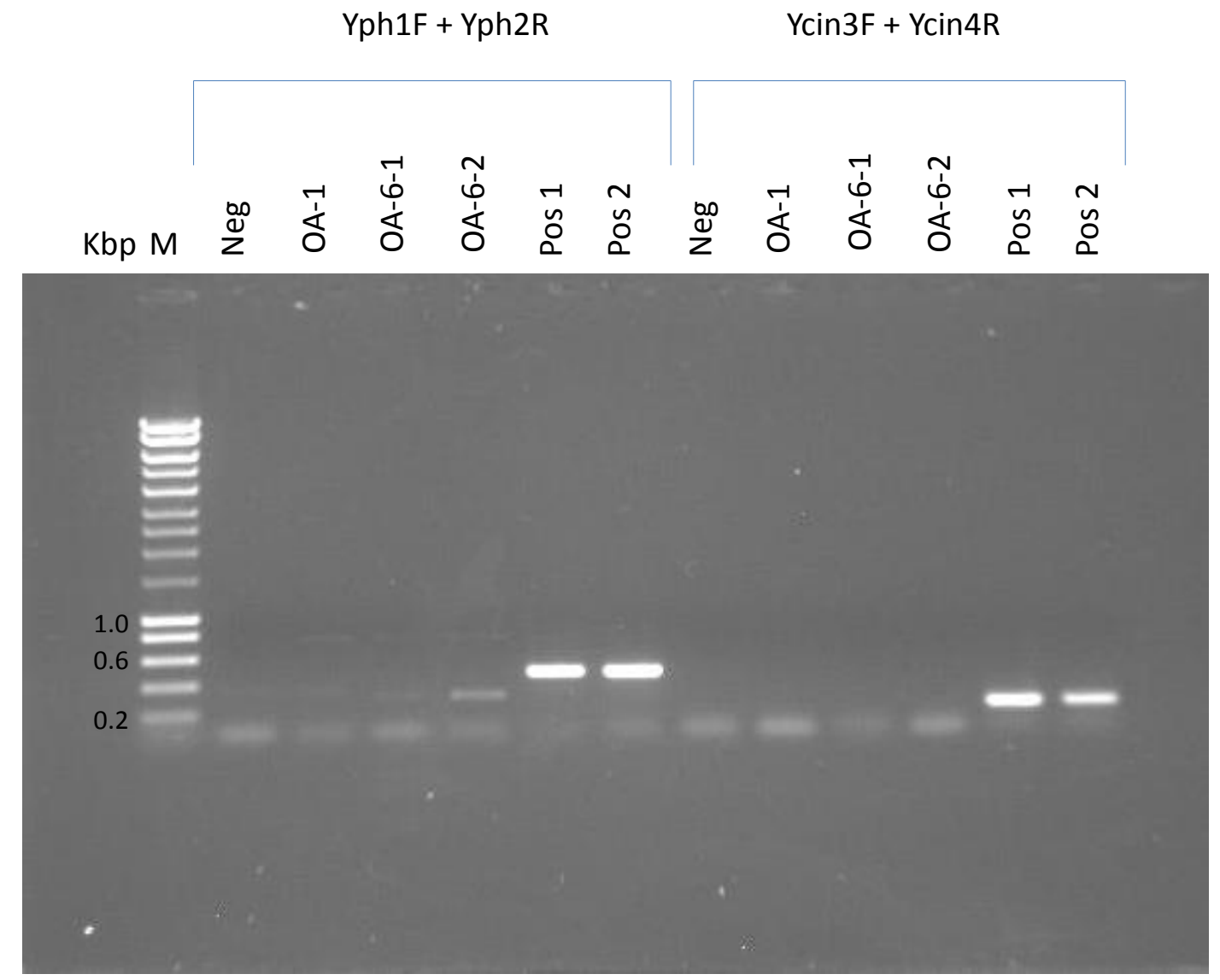

Figure 1. PCR analysis to identify the fungus.

The progress in research efforts to produce blight resistant trees has once again turned the focus on $P$. cinnamomi. Before embarking on restoration plans, one has to make sure that these blight resistant trees will not be susceptible to the equally devastating $P$. cinnamomi. Recent studies have demonstrated the presence of P. cinnamomi in the northern states of West Virginia and Kentucky. However, its spread further north has not happened yet since its presence was observed only in the southern tip of Ohio and Pennsylvania (Balci et al., 2007). It is noteworthy that unlike $C$ parasitica, biology of $P$. cinnamomi makes it harder to establish and spread in cold northern regions. $C$. parasitica is mostly airborne and spreads faster while $P$. cinnamomi spreads slowly and only through soil and water. P. cinnamomi is not cold tolerant and freezing will kill hyphae (Erwin et al., 1983). In areas where the ground freezes down to bedrock, the pathogen will be eliminated. This may be a major reason why the pathogen has not migrated and/or is not 
extensively distributed in northern regions including Ohio. However, with the global warming and species migration due to temperature changes, it is likely that conditions will be favorable in the near future for this pathogen to be widespread in these forests.

It is therefore essential that chestnut restoration efforts should address the blight resistance as well as resistance to $P$. cinnamomi. Such efforts have been underway and recent results have been very encouraging (Jeffers et al., 2009; Jeffers, 2011). The Chinese chestnut is not only resistant to $C$. parasitica, but also to $P$. cinnamomi. Therefore, the hybrid chestnuts being readied for restoration are also somewhat resistant to $P$. cinnamomi. Researchers are further selecting for Phytophthora resistance among these to obtain better progeny. In addition, through genetic engineering Phytophthora resistance is also being incorporated into the chestnut genome (Olukulu et al., 2011).

The fact that we did not find presence of Phytophthora in the location we tested could be due to several reasons. First, as mentioned above, these locations belonged to the northern tip of the spread of $P$. cinnamomi and the pathogen has not had enough time to establish in these locations. Secondly, even if the pathogen had migrated, it may have not been able to survive the freezing conditions. In addition, since these were reclaimed lands, a fresh top soil layer would have been added and the pathogen may not have had time to relocate to these soils. This would be true to locations that were reclaimed recently. However, some locations, as in the Wilds, were reclaimed almost 20 years ago. Even in these areas, we did not find this pathogen. While recently reclaimed locations had just grass growing, others had a mix of tree species planted in adjoining areas, which seemed healthy. Furthermore, it is not known how conducive the harsh soil conditions, such as available nutrients, $\mathrm{pH}$, and other toxic components, are for survival and establishment of the pathogen. If this pathogen cannot survive in the mined lands, they would make highly suitable locations for the American chestnut restoration (Barton et al., 2010). However, more studies and continued monitoring are needed to ascertain this, especially by sampling during different seasons and by mainly using the baiting technique since it handles larger volumes of soil. 


\section{$\underline{\text { Literature Cited }}$}

Altschul, S. F., T.L Madden, A.A. Schaffer, J. Zhang, Z. Zhang, W. Miller, and D.J. Lipman 1997. Gapped BLAST and PSIBLAST: A new generation of protein database search programs. Nucleic Acids Res. 25: 3389-3402.

Anagnostakis, S. L. 1982. Biological control of chestnut blight. Science 215:466-471.

Anagnostakis, S. L. 1987. Chestnut Blight: The classical problem of an introduced pathogen. Mycologia $79: 23-37$

Balci, Y., S. Balci, J. Eggers, W.L. MacDonald, J. Juzwik, R. Long, and K.W. Gottschalk. 2007. Phytophthora spp. associated with forest soils in eastern and north-central U.S. oak ecosystems. Plant Disease 91: 705-710.

Barton, C.D., M.E. French, S. Fei, K.A. Ward, R. Paris, and P. Angel. 2010. Appalachian surface mines provide a unique setting for the return of the American Chestnut. Solutions. Published Online: July 20, 2010. 1 (4) 84-84 http://thesolutionsjournal.com.com/node/688.

Bauman, J.M., C.H. Keiffer, and S. Hiremath. 2012. Facilitation of American chestnut (Castanea dentata) seedling establishment by established Pinus virginiana in mine reclamation. Intn. J. Ecology 10 (doi:10.1155/2012/257326) 11p.

Bauman, J.M., C.H. Keiffer, and S. Hiremath. 2011. The influence of introduced fungal inoculum on root colonization potential and community composition of native ectomycorrhizal species on blight-resistant chestnut hybrids on reclaimed mine sites. National Meeting of the Am. Soc. of Mining and Reclamation, Bismarck, ND Reclamation: Sciences Leading to Success June 11-16, 2011. R.I. Barnhisel (ed.) Published by ASMR, 3134 Montavesta Rd., Lexington, KY 40502. p 16-37.

Bruns, T.D., T.M. Szuo, M. Gardes, K.W. Cullings, J.J. Pan, D.L. Taylor, T.R. Horton, A Kretzer, M. Garbelotto, and Y.Li. 1998 A sequence database for the identification of ectomycorrhizal basidiomycetes by phylogenetic analysis, Molecular Ecology 7: 257-272.

Burnham, C.R., P.A. Rutter, and D.W. French. 1986. Breeding blight-resistant chestnuts. Plant Breeding Reviews 4:347-397. 
Crandall, B.S., G.F. Gravatt, and M.M. Ryan. 1945. Root disease of Castanea species and some coniferous and broadleaf nursery stocks caused by Phytophthora cinnamomi. Phytopathology 35: 162-180.

Danielson, R. 1985. Mycorrhizae and reclamation of stressed terrestrial environments. In Soil reclamation processes. Tate, R. and A. Klein, (eds.) Marcel Dekker, Inc. pp. 173-201.

Erwin, D.C., S. Bartnicki-Garcia, and P.H. Tsao. 1983. Phytophthora : Its Biology, taxonomy, ecology, and pathology. American Phytopathological Society, St Paul, MN, 1983.

Fei, S. 2007. The geography of American place names and the trees. J. Am. Forestry 105 : 84-90.

Gardes, M., and T.D. Bruns. 1993. ITS Primers with enhanced specificity for basidiomycetes application to the identification of mycorrhizae and rusts. Mol. Ecol. 2: 113-118.

Hiremath S.T., and K. Lehtoma. 2007. Ectomycorrhizal fungi association with the American chestnut. Proc. of the 2006 USDA Interagency Research Forum on gypsy moth and other invasive species; 2006 January; Annapolis, MD. p 55.

Jeffers, S.N., J.B. James, and P.H. Sisco. 2009. Screening for Phytophthora cinnamomi in hybrid seedlings of American chestnut. In E.M. Goheen and S.J. Frankel (eds.), Phytophthoras in forests and natural ecosystems. Proc. of the Fourth Meeting of the International Union of Forest Research Organizations (IUFRO) Working Party S07.02.09 Aug 26-31, 2007, Moterey, CA. p. 188-194.

Jeffers, S. 2011. Resistance to Phytophthora cinnamomi among seedlings from backcross families of hybrid American chestnut. Fourth International Workshop on the Genetics of host-parasite interactions in Forestry, Eugene, OR. July 31-August 5, 2011. http://ucanr.org/sites/tree_resistance_2011conference/home/.

Johnson, L.F., and E.A. Curl. 1972. Methods for research on the ecology of soil-borne plant pathogens. Burges Publishing Co. Minneapois, MN.

Maynard, C.A., W.A. Powell, L.D. Polin-McGuigan, A.M. Viéitez, A. Ballester, E. Corredoira, S.A. Merkle, and G.M. Andrade. 2008. Chestnut. In: A compendium of transgenic crop plants: Forest tree species, C. Kole, T.C. Hall, (eds.) Blackwell Publishing, Oxford, UK. 
Nuss, D.L. 2005. Hypovirulence: Mycoviruses at the fungal-plant interface. Nature Reviews Microbiology 3:632-642.

Olukolu, B.A., C.D. Nelson, and A.G. Abbott. 2011. Genomics assisted breeding for resistance to Phytophthora cinnamomi in chestnut (Castanea spp.). Fourth International Workshop on the Genetics of host-parasite interactions in Forestry, Eugene, OR. July 31-August 5, 2011. http://ucanr.org/sites/tree_resistance_2011conference/home/ .

Rhoades, C.C., S.L. Brosi, A.J. Dattilo, and P. Vincelli. 2003. Effect of soil compaction and moisture on incidence of phytophthora root rot on American chestnut (Castanea dentata) seedlings. Forest Ecology and Management 184:47-54.

Rhoades, C., D. Loftis, J. Lewis, and S. Clark. 2009. The influence of silvicultural treatments and site conditions on American chestnut (Castanea dentata) seedling establishment in eastern Kentucky. Forest Ecology and Management 258:1211-1218.

Root, C., C. Balbalian, R. Bierman, L.M. Geletka, S. Anagnostakis, M. Double, W. MacDonald, and D.L. Nuss. 2005. Multiseasonal field release and spermatization trials of transgenic hypovirulent strains of Cryphonectria parasitica containing cDNA copies of hypovirus CHV1-EP713. Forest Pathology 35:277-297.

Schena, L., J.M. Duncan, and D.E.L. Cooke. 2008. Development and application of a PCRbased 'molecular tool box' for the identification of Phytophthora species damaging forests and natural ecosystems. Plant Pathology 57: 64-75.

Sisco, P.H., R.R. Sederoff, J.P. Tomkins, J.E. Carlson, T.L. Kubisiak, M.E. Staton, H.V. Hebard, S.L. Anagnostakis, W.A. Powell, and C.P. Smith. 2009. The United States National Science Foundation project on developing tools for the study of the Fagaceae: Castanea, Quercus, and Fagus. Acta Hort. (ISHS) 844:267-274. 